\title{
INVESTIGATED THE IMPLEMENTATION OF MAP LITERACY LEARNING MODEL
}

\author{
Nuansa Bayu Segara ${ }^{1}$, Enok Maryani ${ }^{2}$, Nana Supriatna ${ }^{3}$, Mamat Ruhimat ${ }^{4}$ \\ ${ }^{1}$ Faculty of Teacher Training and Education, Swadaya Gunung Djati University (Unswagati) Cirebon, Indonesia \\ ${ }^{2,4}$ Department of Geography Education, Indonesia University of Education, Bandung, Indonesia \\ ${ }^{3}$ Department of Social Science Education, Indonesia University of Education, Bandung, Indonesia \\ Email : nuansasegara88@gmail.com
}

Received: 10 June 2018/Revised: 17 July 2018/Accepted: 18 August 2018/Published online: 28 August 2018

\begin{abstract}
This article presents the results of the first implementation of map literacy learning model in middle school classes - this is the preliminary test. The implementation of this learning model will gain optimal results when it is conducted by following all the component of the model such as the syntax, theoretical framework, social system, teachers' roles, and support system. After the model implementation has been completed, the results showed that there was significantly different in students' spatial thinking skills before and after the treatment. However, the implementation also revealed that the model has some technical issues and thus to be improved. In a social system revision, the teacher has to be flexibly provide scaffolding every time he/she sees that the students need it. Teacher's book is significantly important to help a teacher lead the learning process. After improvement of the model has been completed, then it is ready to be implemented in the main field testing stage.
\end{abstract}

Keywords: map literacy, social studies learning, spatial thinking

\section{Introduction}

Social studies in schools requires innovations tailored to millennial needs. The digital literacy era directs humans to be able to understand information in various forms. Graphs, diagrams, timelines, and maps are a means of delivering information that is considered efficient in disseminating data. IPS has the opportunity to facilitate learners to learn the skills needed this century. Social studies learning is an integrated multidisciplinary learning to prepare learners to be competitive citizens (Brophy \& Alleman, 2009; NCSS, 2016).

Learners are prepared to have various skills aiding them in carrying out daily activities. Thatrequired skill is spatial thinking. Over the last decade, spatial thinking has become an intriguing and intensively studied topic. There is a development of the term from spatial thinking into geospatial thinking (Huynh \& Sharpe, 2013; Ishikawa, 2012; Verma, 2014). Geospatial thinking focuses on spatial skills associated with the earth's surface as 
space. Conceptually, this skill is very appropriate to be taught in social studies education. Spatial thinking is very important because it is needed in various activities and daily mobility, workplace and science (National Reseach Council, 2006). This skill is important to be mastered by students early on, because it will make it easier for them to travel, to understand the space in mall, market, game room, tourist attraction, therefore preventing them from getting lost. Work in the current era also increasingly requires spatial thinking, such as architects, scientists, geologists, engineers, surveyors, etc. In addition, the development of science also requires spatial thinking, such as astronomy, geology, geography or even social science research (Logan, 2012; Logan, at al., 2010).

The spatial thinking concept referred to in this article is the knowledge, skills and cognitive operations associated with the use of spatial concepts, the representation of tools and reasoning processes in a geographic context. (Huynh \& Sharpe, 2013; National Reseach Council, 2006). Spatial thinking is an integral part of everyday activities, human, natural objects, man-made objects exist in one unity of space, the interaction between humans requires an understanding of location, distance, spatial patterns, clues and other space concepts (National Reseach Council, 2006). The development of spatial thinking can be done through increasing the map literacy. This skill becomes one of the competencies that must be achieved in the social studies curriculum in Indonesia, this learning has the opportunity to explore students' skills in reading, interpreting, analyzing and using maps.

The social studies curriculum in Indonesia as an interdisciplinary study (geography, sociology, history, economics) has the opportunity to develop spatial thinking skills. The learning requires comprehensive innovation and can be utilized practically in an effort to develop that skill. The very possibility of innovation required and appropriate to the nation's culture is to develop a cooperative learning model. This is consistent with several recommendations, spatial thinking and map literacy development based on cognitive social developmentlearning theory, which is presented in cooperative learning (Adeyemi \& Cishe, 2015; Gauvain, 1993; Verma, 2014; Wiegand, 2006 ). The recommendations and views of these scientists form the basis for developing a model of map literacy learning based on Vygotsky's cognitive social learning theory.

The result of requirement analysis strongly supports the development of learning model that utilizes the map as media and learning resources, social studies teachers in Cirebon City still find it difficult to make integrated social studies learning based on four disciplines of social sciences (geography, economy, history, and sociology) to become the main core in social studies curriculum in Indonesia. Teachers need an social studies learning 
platform that is able to integrate content from social science disciplines. By using maps will be ideal and optimal if integrated into a social science or multidiscipline (Bednarz, at al., 2006; Hribar, 2015). Social studies teachers in Cirebon City have 77,6\% confidence that learning by using a map as media and learning resource can make social studies more integrated. They are convinced that map literacy will accommodate content derived from social studies classes.

Other results of the analysis reinforce that map literacy learning model needed is described as follows: 1) The majority of social studies teachers mostly usediscussion or cooperative learning method in the classroom; 2) The majority of teachers stated, that learners are very positive ona discussion or cooperative learning model. These results exhibit that learning-oriented towards cognitive development through social interaction is very relevant to be developed. For that, it is appropriate that the Map Literacy Learning Model is based on Vygotsky's grand-cognitive theory. Socio-cultural cognitive development Vygotsky is the part of constructivism educational approach. In constructivism, student collaborative, small group works, social interaction between students and teacher or peer learner are accentuated (Durmuş, 2016).

The main focus of this research is to ensure that map literacy learning model and its components such as syntax, social systems, teacher roles and support systems (Joyce, at al., 1978) are implemented optimally. To identify the deficiencies or weaknesses in the learning model so that it can be improved or refined. Learning process technique will also be a concern because it is possible that there is a difference in teacher's perception regarding model implementation procedure. In addition, to determine whether the map literacy learning modelis able to achieve instructional impact, namely to develop spatial thinking skills.

\section{The Methods}

\subsection{Experiment Design}

The preliminary test uses a one-group pretest-posttest design pre-experimental procedure in three steps (Gall, at al., 2003): 1) administration of a pretest measuring the dependent variable; 2) implementation of the experimental treatment (independent variable) for participants: and 3) administration of a pretest measuring the dependent variable. The effects of the experimental treatment are determined by comparing the pretest and posttest scores. Treatment will be done three times. Each completed treatment will be evaluated and improved. So teachers participating in this test will get input and criticism after the treatment, 
as one of the main focuses of this preliminaryexperiment is to refine the map literacy model to be ready for a wider test.

\subsection{Sample}

The test was conducted in one of State Junior High School Cirebon, Indonesia. Schools are chosen because of the learners characteristic that matches the criteria required for examination. Because in general, this school is not a pre-eminent school. Being in the suburbs, this school belongs to the middle class. The population in this test is all students of State Junior High School Cirebon. Samples were taken purposively taking into account learners characteristics.Class VII-F with the number of 34 students were selected. According to teachers who carry out the test, learners characteristic in this class tend to be passive and not enthusiastic when teachers innovate in the learning process. At first, the teacher hesitated to choose this class as a test subject, but because it was convinced that the criteria fit perfectly with the needs of the test, the teacher finally agreed.

\subsection{Data Analysis}

Worksheet are designed for active learners to work out group (task) challenges. The results of the learners' performance during the learning process were analyzed through descriptive statistics. Furthermore, data analysis techniques are performed to see the improvement of spatial thinking skills by testing the n-gain. A paired t-test was performed to test the effect of the model to improve spatial thinking skills. Prior to that, there will be a pre-requisite test of normality and homogeneity. Test normality was conducted usingShapiro-Wilktest and homogeneity by doing Levine test.

\section{Results and Discussion}

\subsection{Map Literacy Learning Model}

The map literacy learning model is a product developed in this study. Model development was conducted because IPS learning in Indonesia requires an applicative and practical platform for classroom practice. Model design is based on a deep literature review of spatial thinking skills developed in the classroom and adapts to social studies learning needs that are factually identified through need assessment. The learning model is a series of learning activities pattern designed to achieve certain goals. Map literacy study is designed to achieve the specific goal of spatial thinking skills development. A learning pattern that 
focuses on map usage in social studies learning is structured systematically into a map literacy learning model, defined as,

"The sequence of learning activities in social studies learning is consistent and focused on using and utilizing maps as media and learning resources designed to develop spatial thinking skills."

Model syntax consists of four steps, namely: primitive literacy, orientation, association, and reflection. The primitive literacy is the first stage in this model. At this stage, students will actively observe the map. The basic question that guides students in this stage is "what's seen?". They will identify the location, symbol, place identity, magnitude on the map. The stages are expected to maximize the literacy capability of the map and the concept of space. Then they interpret the spatial information on the map and match it to the symbol contained in the legend. The second stage is "Orientation", students will be given direction about the purpose and use of maps in learning. After learning the purpose of learning and the use of maps, students are asked to perform tasks that are appropriate for that purpose. Assignments are related to the development of cognitive processes associated with the concept of space on the map. The third is the "Association" stage, where students develop interactive thinking processes. Students will be given a difficult task, and provide an opportunity to complete it in groups. Exploration of cognitive development will occur through the social interaction that occurs during this stage.

The social system formed in this model is the development of knowledge through social interaction, thus creating a learning environment. The role of teachers is very important as a facilitator, mediator, tutor, and motivator during the process of learning model implementation. Teachers will be instrumental during the learning process. The teacher's most important role is to provide scaffolding to students in need. Although the implementation of learning is done in groups, students will still need scaffolding from teachers to achieve learning objectives. In addition, teachers play a role in maintaining ZPD learners. This is necessary so that students continue to maintain a sense of curiosity and have the motivation to learn, therefore creating better cognitive development. Bringing tasks that need to be solved together encourage better development of students' thinking skills (Cohen, at al., 2010). ZPD based on the collaboration of social interaction with teachers will be better than what can be achieved alone (Abbasnasab, at al., 2012; Fani \& Ghaemi, 2011).

Through map literacy learning model, social studies learning will become powerful. So in the learning activity, learners will actively use the map in social studies learning. The map used exhibits the location around the student's residence, with the process, makes it 
possible to realize active, integrated, value-based, meaningful and challenging social studies learning, therefore powerful learning is realized. The development of map literacy skills will be very significant in the implementation of this model. This means that learners will be able and accustomed to read, interpret, analyze, draw and use the map actively. Supported on the assumption that the literacy of the map will improve one's spatial thinking ability (Bednarz et al., 2006; Uttal, 2000), it is most relevant if the instructional objective of this model is to develop spatial thinking skills.

\subsection{Model Treatment}

Model implementation was planned to be completed in three meetings. Basic competencies in the three meetings are "Understanding the concept of space (location, distribution, potential, climate, earth form, geology, flora, and fauna) and inter-space interaction in Indonesia and its impact on human life in economic, social, and education ". This is adapted to the instructional objectives in this research namely spatial thinking skills. The material discussed and the learning objectives of each meeting will be different. Obviously, that goal will be aligned with indicators of spatial thinking skills, namely: the concept of space; tools of representation, and reasoning process (National Reseach Council, 2006). Treatment was conducted three times, with the hope that learners will gradually build and develop those skills through learning map literacy.

The first treatment aimed to build an understanding of map concept, as well as improving the basic literacy skills such as reading, interpreting and analyzing maps. The second meeting focuses on the introduction of the contour line to understand the altitude of a place on the map. The third meeting is the development of map analysis skills and their relationship to spatial information. Each meeting is reflected together with the model teacher. The goal is to find the best implementation of the map literacy learning model, as well as to receive input and criticism from the teacher for the basic refinement of the model under test.

The first treatment did still experience a number of deficiencies in the implementation. Teachers revealed several obstacles encountered during the preliminary test process, namely:

- Teachers are still confused in carrying out the stages in the map literacy learning model.

- The map media used was not printed well, therefore learners have difficulties in working on the challenges that teachers provide through the worksheet. 
- Learners are very slow in performing the task given by the teacher, therefore not all the steps of map literacy learning was achieved.

Researchers conducted theoretical and practical studies on learning models related to the development of the map literacy model. The main focus is the adjustment of the Vygotsky Theory (the main theory of developing a map literacy model) with technical learning in the classroom. The most important conclusion of these search results is improvements in the social system of the map literacy learning model. At the first meeting, students are asked to work individually, but they are difficult and ultimately unable to solve the challenge, for which the social system needs to be changed, that is by asking learners to establish social interaction organized by a leader and do direct scaffolding in the first stage of learning. Scaffolding conducted in the learning process is done by the leader to its members, or fellow group members and teachers to learners. Scaffolding is done to help learners gain meta cognition maximally (Joyce, at al., 2009). The form of scaffolding provided is to help in accordance with what the learners need or to observe the will and effort of the learners and provide light help if the student is in doubt, the teacher will give encouragement. Teachers will continue to provide motivation and encouragement to learners to train their skills in map literacy. Teachers should continue to provide encouragement and motivation for students to collaborate in solving the challenges provided. Learners need to be constantly reminded to form a learning community in the process of learning map literacy. Teachers will conduct personal a worksheet to all learners in the classroom to continuously provide the necessary assistance and encouragement.

The proximal development zone will also continue to be monitored by teachers and group leaders. Learners will continue to get challenges in the form of tasks available on the worksheet. Teachers will continue to encourage learners to rise to higher levels in map literacy learning. Challenges from one stage to another are increasingly difficult and there is a need for cooperation between them, hence creating a learning society. The following is the formulation of constraints and improvement plans that will be made in the second preliminary test. 
Table 1. The First Meeting Model Test Improvement Plan

\begin{tabular}{lll}
\hline No & $\begin{array}{l}\text { First Preliminary Test } \\
\text { Constraints }\end{array}$ & Second Preliminary Test Improvement Plant \\
\hline $\mathbf{1}$ & $\begin{array}{l}\text { Apperception caused the } \\
\text { learners to be not prepared }\end{array}$ & $\begin{array}{l}\text { Teachers explore learners' knowledge more contextually, such } \\
\text { as asking for interesting locations, tour activity activities, and } \\
\text { other activities that require maps. or }\end{array}$ \\
\hline $\mathbf{2}$ & $\begin{array}{l}\text { Incomplete learning model } \\
\text { syntax due to time } \\
\text { constraint }\end{array}$ & $\begin{array}{l}\text { Teacher brings learners into a challenging game (tasks). } \\
\text { Teachers manage time effectively at each learning step. } \\
\text { Teachers condition learners effectively in the process of group } \\
\text { formation. }\end{array}$ \\
\hline $\mathbf{3}$ & $\begin{array}{l}\text { Slow and incomplete } \\
\text { student work execution in } \\
\text { every learning step. }\end{array}$ & $\begin{array}{l}\text { Tasks were conducted in groups, led by a group leader to } \\
\text { manage the discussion process. Teachers provide Scaffolding } \\
\text { (assistance) in assignments at every learning step. Teachers } \\
\text { provide direction for learners to optimize the "difficulty notes" } \\
\text { column in the worksheet. Teachers remind the learners to be } \\
\text { quicker and more focused on the task. }\end{array}$ \\
& $\begin{array}{l}\text { First worksheet design is } \\
\text { less communicative. }\end{array}$ & $\begin{array}{l}\text { Improved worksheet format in the first task. } \\
\text { The map media is further clarified and eliminated the map } \\
\text { elements causing difficulty on the learners part. }\end{array}$ \\
\hline
\end{tabular}

After formulating improvement plans in the next learning process, researchers and teachers discuss the formulation. Researchers reveal what improvements need to be done so that the process of learning the literacy model goes well and achieves the learning objectives. The planned improvements comprised almost all components of the learning model, such as the syntax implementation process, the built social system, the role of the teacher, and the support system. The teacher wisely reflects on the shortcomings that exist in the learning process in the first test and is ready to improve in accordance with the reform plans that have been formulated.

The researcher reflects and evaluates the implementation of the second test. There following are several improvement needs to be undertaken at the third meeting related to, apperception, social system (group leader determination), syntax (challenge review did regularly and accommodate all learners), support system (use of column note difficulties on worksheet needs to be optimized and monitored). The following are details on improvement plan that will be made in the thirdtest. Improved plans are then submitted to teachers for study. The teacher openly accepted the improved plan. Preparation is then done by teachers to continuously improve the quality of map literacy learning in various aspects, both technical and non-technical. Teachers who have been assessed on learners' 
performance will know who or which group needs more help and which ones already have the independence in learning.

Table 2. Second Test Model Improvement Plan

\begin{tabular}{llrl}
\hline No & $\begin{array}{l}\text { Second Preliminary } \\
\text { Constraint }\end{array}$ & Test & Third Preliminary Test Improvement Plan \\
\hline $\mathbf{1}$ & $\begin{array}{l}\text { Apperception regarding lesson } \\
\text { context is not relevant to students } \\
\text { daily activity. }\end{array}$ & $\begin{array}{l}\text { Apperception is expected to be more contextual and } \\
\text { associated with the participants' daily activities. } \\
\text { Learners are reminded of materials learned during the } \\
\text { previous meeting. }\end{array}$ \\
\hline $\mathbf{2}$ & $\begin{array}{l}\text { The group leader has not played an } \\
\text { active role in assisting members } \\
\text { experiencing difficulty }\end{array}$ & $\begin{array}{l}\text { The teacher determines group leader according to his / } \\
\text { her abilities. Teachers motivate and counsel to } \\
\text { establish cooperation and help each other in the } \\
\text { learning process. }\end{array}$ \\
\hline $\mathbf{3}$ & $\begin{array}{l}\text { The "difficulty note" column is not } \\
\text { yet optimally used. }\end{array}$ & $\begin{array}{l}\text { The teacher emphasizes how important the difficulty } \\
\text { note is used.Teachers monitor the use of difficulty } \\
\text { notes in the learning process. }\end{array}$ \\
\hline $\mathbf{4}$ & $\begin{array}{l}\text { The material notes that suggest the } \\
\text { study's main purpose are not optimal. }\end{array}$ & $\begin{array}{l}\text { The teacher reminds the completeness of the learner's } \\
\text { notes in the worksheet.Monitoring is done by group } \\
\text { members. }\end{array}$ \\
\hline $\mathbf{5}$ & $\begin{array}{l}\text { The absence of a review of joint tasks } \\
\text { between learners and teachers before } \\
\text { study period ends }\end{array}$ & $\begin{array}{l}\text { Teachers and learners conducted the review on task } \\
\text { item during the reflection process. }\end{array}$ \\
\hline
\end{tabular}

The shortcomings that exist in the implementation of the third meeting model are taken into notes. Researchers formulated solution afterward. Improvements that need to be done at the fourth meeting is only a technical implementation on learning process to improve learning quality. In general, the implementation of learning in the last two meetings exhibits a positive trend almost in the overall model structure, such as the social system, the role of an optimal teacher, complete syntax, and support systems.

The main goal of improvement at the fourth meeting is to increase the participation of learners in the association process. Through the process of association, the learners will develop the knowledge and ability to think on a higher level. Interactions built between group members are also expected to form a learning community. Learners will be familiar with the process of asking, expressing opinion and argument, as well as seeking answers together. Through such a process their abilities in map literacy and spatial thinking ability will flourish.

After the formulation of the improvement plan is completed, the researcher sends the formula to the teacher. Teacher asks a few examples of learning types. The researcher gives an explanation to the teacher of the technique model practiced in the implementation of the fourth test. Teachers and researchers make the necessary preparations for the implementation of the test, after all, is completed, then the process of conducting fourth test learning model begins. 
Table 3. Third Test Model Improvement Plan

\begin{tabular}{lll}
\hline No & $\begin{array}{l}\text { Third Preliminary Test } \\
\text { Constraint }\end{array}$ & Fourth Preliminary Test Improvement Plan \\
\hline $\mathbf{1}$ & $\begin{array}{l}\text { Discussion process has not run } \\
\text { optimally, some groups help each } \\
\text { other by giving a direct answer, } \\
\text { not teaching each other. }\end{array}$ & $\begin{array}{l}\text { Teachers remind learners to work together with each } \\
\text { other instead of providing answers directly.Teachers } \\
\text { continue to motivate learners to continue to help each } \\
\text { other and communicate at each stage of learning. }\end{array}$ \\
\hline $\mathbf{2} \quad \begin{array}{l}\text { Learners do not know the } \\
\text { learning stage. }\end{array}$ & $\begin{array}{l}\text { At the second meeting, the teacher has written step by } \\
\text { step learning model. It should be rewritten at the fourth } \\
\text { meeting. }\end{array}$ \\
\hline $\mathbf{3} \quad \begin{array}{l}\text { At the "association" stage the } \\
\text { teacher has not involved each } \\
\text { group to actively give an opinion, } \\
\text { exhibiting their work result. }\end{array}$ & $\begin{array}{l}\text { When re-discussing conducted tasks teachers appoint the } \\
\text { group in turns of their work and ask the whole group } \\
\text { whether there are similarities and differences in their } \\
\text { work. }\end{array}$ \\
\hline
\end{tabular}

Model implementation at the fourth meeting runs as expected. The entire syntax is very well passed. Significant improvement is exhibited in the interaction between learners. Some of the group members who were passive in previous discussions began to exhibit courage to argue and define attitudes in answering group tasks. Teachers already understand the role in the implementation of this model. The role of the facilitator is clear in helping learners to understand the built knowledge. Teachers acts as a facilitator during discussion process as reflection stage took place. Implementation of map literacy learning processwas conducted in four meetings. The second meeting is the repetition of the first meeting. During this process, learners work on the challenges provided through the worksheet. Learners work result is one of observers' assessment factor in this research.

\subsection{Learning Process Achievement}

Maps literacy learning process was conducted in groups. Performance assessed is done individually whereas for the description exhibitted in this discussion was based on the group work. This performance achievement is the accumulation of correct answers from the worksheet done by learners during the learning process. The following are achievements of the learning process in the three meetings conducted in a preliminary test of the learning model. 
Table 4. Learners Performance AchievementDuring Learning Process

\begin{tabular}{ccccc}
\hline Group & \multicolumn{4}{c}{ Achievement Process (\%) } \\
\cline { 2 - 5 } & Treatment 1 & Treatment 2 & Treatment 3 & $\sum$ \\
\hline $\mathbf{1}$ & 48,72 & 69,23 & 85,42 & 67,79 \\
\hline $\mathbf{2}$ & 53,85 & 70,77 & 92,71 & 72,44 \\
\hline $\mathbf{3}$ & 65,38 & 68,27 & 88,54 & 74,06 \\
\hline $\mathbf{4}$ & 72,31 & 57,69 & 89,17 & 73,06 \\
\hline $\mathbf{5}$ & 56,73 & 67,95 & 91,67 & 72,12 \\
\hline $\mathbf{6}$ & 61,54 & 73,08 & 78,88 & 71,17 \\
\hline $\mathbf{7}$ & 53,85 & 48,08 & 83,33 & 61,75 \\
\hline$\Sigma$ & 58,91 & 65,01 & 87,10 & 70,34 \\
\hline
\end{tabular}

Source: Research Result 2017

The average performance outcomes of the learning process undertaken on tests confined to three meetings exhibit an increasing trend. The first meeting, the accumulative performance achievement class only reached $58.91 \%$. The second meeting was the improvement of the learner's performance during the map literacy learning process with the achievement of $65.01 \%$. The increase occurred again in the third meeting with the achievement of the learners' performance at $87.10 \%$. Average achievement during the implementation was $70.34 \%$. This means that the learners in the test subject class during the test process successfully worked out $70.34 \%$ of all challenges provided correctly.

Considering performance results that improved at each meeting, very directly proportional to the interaction built-in groups. The group interaction in each meeting has increased, as seen from the higher class participation from the first meeting until the third meeting. Leaders who become facilitators in the discussion process are also quite instrumental in building social interaction.

In general, the interaction formed to build knowledge is going according to plan. There are only two groups with low social interaction. Based on the observations of teachers and researchers there are two weaknesses when the group conducts discussions. First, the group leader took a less active role in motivating group members to think in solving the challenge. Second, group members do have capabilities that are under the leader, work progresses slowly, even though they seem to be trying to solve it.

Special notes that need attention in implementing the literacy learning model in the classroom are thoroughly possible to form a social interaction that makes learners feel comfortable in the process of knowledge building. Learners should be comfortable, unencumbered with the tasks assigned, therefore, the teacher should act as a facilitator, 
motivator, and good evaluator during the learning process. Learners should be in good condition to learn, so have a passion, high curiosity, and totality in solving the challenges given.

\subsection{Spatial Thinking Skills Development}

This preliminary testing is focused on developing the implementation and technical model of learning literacy map, but it is also important to know how the readiness of Lita learning model in improving spatial thinking skills become the dependent variable in this study. Pretest and posttest conducted before and after implementation of the map literacy learning model. Pre and post test contains same problem in the form of an objective test consisting of 18 multiple choice questions. The following is the acquisition of pre and post test of spatial thinking skills during the preliminary test in class.

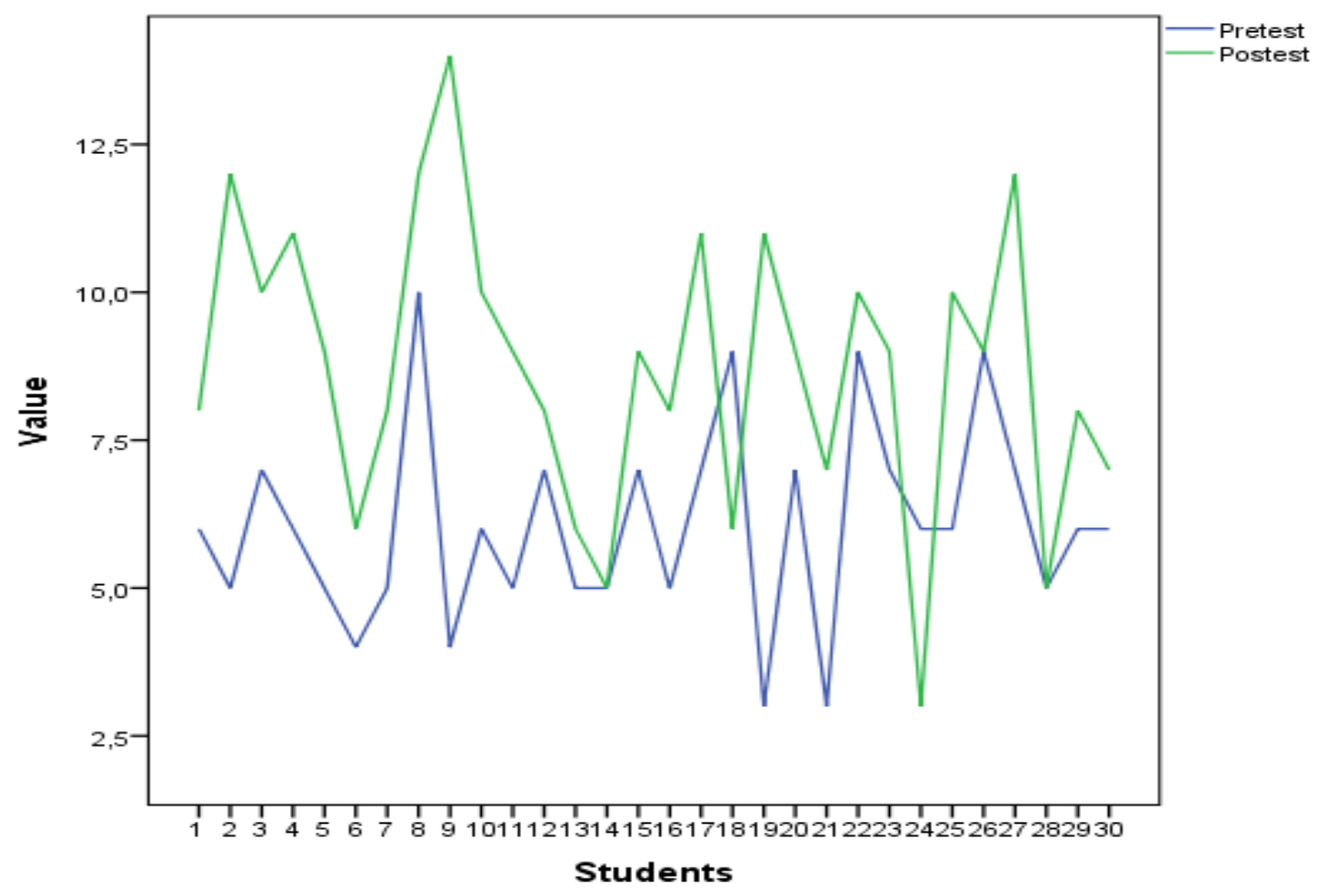

Figure 1. Comparison of Pre and Post Spatial Thinking Skills Value

The graph exhibits the results of spatial thinking skills before and after a preliminary test. In general, there is an increase between pre-test and post-test. On the average pre-test 6,07 with the highest score is 10 points, while the average in the post-test of 8,73 with the highest score of 14 points.A trend appears in the figure is that there is an increase in the result of pre- and post-test geospatial thinking skills. Several learners are actually maintaining their result but there are also who experience deterioration, however; the result is not really small compared to the number of students experiencing improvement 
Difference analysis of pre- and post-treatment geospatial thinking skills will be performed through statistical calculation. However, it should be preceded by data normality test using Shapiro-Wilk calculation. The result of pre- and post-test result reveals that the data does meet the criteria to be normal. According to the normality test, then it decides that pre- and post-test difference analysis is performed using parametric statistics (Paired T-test)

Table 5. The Result of Normality Test

\begin{tabular}{llll}
\hline & Shapiro-Wilk & Sig & Conclusion \\
\hline Pretest & 0,938 & 0,080 & non-significant \\
\hline Posttest & 0,983 & 0,883 & non-significant \\
\hline
\end{tabular}

Source: Research Result 2017

The value of n-gain is 0.21 , which means that the learners' improvement of spatial thinking in the test class is preliminary to the middle category. Overall learners have improved in geospatial thinking skills after implementing the learning process through the map literacy model.

Table 6. Average pretest-posttest, n-gain, t, Significancy Conclusion

\begin{tabular}{llllll}
\hline Pretest & Posttest & n-gain & Z & P-Value & Conclusion \\
\hline $\mathbf{6 , 0 7}$ & 8,73 & 0,211 & $-3,885$ & 0,000 & $\begin{array}{l}\text { Significantly } \\
\text { different }\end{array}$ \\
\hline
\end{tabular}

Source: Research Result 2017

T test is performed to know the difference result between pre- and post-preliminary test geospatial thinking skills. The result reveals that there is a significant difference at preand post-treatment. Map literacy model has an ability to facilitate students to develop their geospatial thinking skills. This model shows that the learning focuses on spatial knowledge development and spatial concept conducted through map literacy, i.e. reading, describing, analyzing, and drawing a map. Those skills are accommodated through syntax. The students build spatial skills through an activity arranged within map literacy activity.

This research does not only focus on geospatial thinking test results but also gives a bigger emphasis on investigation of the lacks of map literacy learning model in its application, both technically and also considering the performance of model components. Identification is conducted based on the research observation, students respond to the process of model application, and evaluation from a teacher practicing this model in a classroom. According to the investigation result, it is expected to give an input that can be considered to refine this map literacy model. 
There are several findings that will be used as a basis for developing learning models. The preliminary test process strongly supports the theory used, as well as the use of the principles of the learning model is directly proportional to the learning process and the results in this study. The following are some findings that can be identified in the implementation of map literacy learning model, as well as improvements made based on the findings of conducted preliminary test.

The syntax is essential in a process of map literacy model performance. This has been arranged to improve spatial thinking skills, three first steps are: primitive literacy, orientation, and an association is a stage where a student gets a challenge designed to build his/her knowledge of the spatial concept, tool usage and spatial problem-solving. The obstacles faced relate to the syntax are at the first meeting the syntax is not over, the reason is that the students are categorized into slow-learners. Asa (1951) has a facility to overcome this problem, this kind of student cannot be forced to learn a map so that they have to pass through a continuing process and needs to relate to mapping concepts with their daily experiences. For that matter, an appreciation to do has to be truly meaningful or contextual with students' environment, so that they are interested in and able to associate map and their environment.

The social system of this research is built on Vygotsky theory. The learning process with their small group is very efficient to develop students' knowledge on a map. The students have to feel comfortable in a learning process, they have to consider their friends are people who are able to help, motivate and increase learning quality. They will also cooperative to do the assignment by discussing, debating, arguing so the task given will be finished. It is revealed that social interaction-oriented map learning is more effective than individual oriented (Adeyemi\&Cishe, 2015; Leinhardt, at al., 1998; Saekhow, 2015). This model will defend small group working focusing on ZPD development through Scaffolding between students and teacher.

The teacher has an essential role in the process of map literacy learning. The students truly need others' help to pass their ZPD. The teacher is the best one to give scaffolding when students need it. The scaffolding given will be saved in a memory and will be recalled if they need to understand their environment in the future (Churcher, at al., 2014). For that matter, teacher's role in the implementation of this role is important, and they need to understand how big the role of students thinking development.

Learning with literacy model has a principle to do. Powerful social studies (NCSS, 2016) is a concept developing principles within map literacy learning model. Map use as 
learning resources has to be meaningful, concept explanation, principle, logical argument, and high generalization from various foundations will be truly hard given to the young learners (Brophy\&Alleman, 2009). Therefore, map literacy learning model will build required knowledge like content factual, personal experience, and daily activity relationship with the student through a map. Key, Bradley \& Bradley (2010) says that "literacy is a natural component of social studies, and the social studies teacher is the key to successful literacy studies development in the field". Map literacy is an inseparable part of social studies learning, and teacher's role is essential to enhance social studies leaning quality through map literacy. It is required high competence of teacher in practicing technology innovation in social studies learning so that the development of learning model can enhance teacher skill in practicing innovative findings in the education field, especially social studies. model development. According to the literature search, theory reinforcement and input from teachers and students participating in the preliminary test, so that it is decided to revise map literacy learning model. Following is the table describing the findings of model trial and model revision as a stage in map literacy.

\section{Conclusion}

Map literacy learning model can technically be implemented well. Although in each treatment is still needed technical improvements. Model components such as syntax, teacher roles, social systems, modeling principles and support systems need to be thoroughly and in accordance with the theory. Implementation result of map literacy learning modelexhibits a positive tendency. There is an improvement in spatial thinking skills between before and after the implementation of the map literacy learning model. This means that this model successfully achieved the instructional objectives in the implementation process. Based on the observations and results of this study, the map literacy learning model was redeveloped by improving some of the deficiencies in the model, particularly in the components of social systems, teacher roles, and systems, supporters.

The model in this study is still not perfect, as further development, this model will be refined based on the findings during the limited trial process. Some of the things that will be done in the advanced model development is arranging teacher's handbook for technical implementation of the model, refining map as the media used, increasing teachers' role understanding to the model comprehensively, and improving the quality of student worksheet to be easier to understand, work and help learners build their knowledge. All of 
that must be in accordance with the theoretical basis which becomes the basis for Vygotsky's Socio-cultural Development. After the model has been refined, it will experience an operational field testing, then the model is refined, and the last is performingmain field testing.

\section{References}

Abbasnasab, S., Rashid, M., \& Saad, M. (2012). Knowledge with Professional Practice A Sociocultural Perspective on Assessment for Learning: The Case of a Malaysian Primary School ESL Context, 66, 343-353. http://doi.org/10.1016/j.sbspro.2012.11.277

Adeyemi, S. B., \& Cishe, E. N. (2015). Effects of Cooperative and Individualistic Learning Strategies on Students' Map Reading and Interpretation. International Journal of Arts \& Sciences, 8(7), 383-395.

Bednarz, S. W., Acheson, G., \& Bednarz, R. S. (2006). Maps and Map Learning in Social Studies. Social Education, 70(7), 398-404. http://doi.org/10.4324/9780203841273

Brophy, J., \& Alleman, J. (2009). Meaningful social studies for elementary students.

Teachers and Teaching, 15(3), 357-376. http://doi.org/10.1080/13540600903056700

Cohen, L., Manion, L., Morrison, K., \& Wyse, D. (2010). A Guide To Teaching Practice (5th ed.). London and New York: Rotledge.

Churcher, K. M. A., Downs, E., \& Tewksbury, D. (2014). “Friending” Vygotsky: A Social Constructivist P edagogy of Knowledge Building Through Classroom Social Media Use, 14(1), 33-50.

Durmuş, Y. T. (2016). Effective Learning Environment Characteristics as a requirement of Constructivist Curricula: Teachers' Needs and School Principals' Views.

International Journal of Instruction, 9(2), 183-198. http://doi.org/10.12973/iji.2016.9213a

Fani, T., \& Ghaemi, F. (2011). Implications of Vygotsky's Zone of Proximal Development ( ZPD ) in Teacher Education: ZPTD and Self-scaffolding. Procedia - Social and Behavioral Sciences, 29(Iceepsy), 1549-1554. http://doi.org/10.1016/j.sbspro.2011.11.396

Gauvain, M. (1993). The Development of Spatial Thinking in Everyday Activity. Developmental Review, 13, 92-121.

Hribar, G. C. (2015). Using Map-Based Investigations with Elementary Students. In ESRI Education GIS Conference (pp. 1-26).

Huynh, N. T., \& Sharpe, B. (2013). An Assessment Instrument to Measure Geospatial Thinking Expertise An Assessment Instrument to Measure Geospatial Thinking Expertise. Journal of Geography, 112(October 2014), 3-41. http://doi.org/10.1080/00221341.2012.682227

Ishikawa, T. (2012). Geospatial Thinking and Spatial Ability: An Empirical Examination of Knowledge and Reasoning in Geographical Science. The Professional Geographer, (July 2015), 121018062625002. http://doi.org/10.1080/00330124.2012.724350

Jessie A. (1951). Maps and Slow-Learners. Journal of Geography, 50:4, 145-149, DOI: 10.1080/00221345108982661

Jo, I., Bednarz, S., \& Metoyer, S. (2010). Selecting and Designing Questions to Facilitate Spatial Thinking. The Geography Teacher, 7(2), 49-55. 
http://doi.org/10.1080/19338341.2010.510779

Joyce, B.R., Weil, M., \& Calhoun, E. (2014). Models of Teaching (8th Ed). New Jersey: Pearson Education.

Key, L.V., Bradley, J.A., \& Bradley, K.A. (2010).Stimulating Instruction in Social Studies. The Social Studies, 101:3, 117-120, DOI: 10.1080/00377990903283932

Leinhardt, G., Stainton, C., \& Bausmith, J. M. (1998). Constructing Maps Collaboratively. Journal of Geography, 97(1), 19-30. http://doi.org/10.1080/00221349808978821

Logan, J. R. (2012). Making a Place for Space: Spatial Thinking in Social Science. Annual Review of Sociology, 38(1), 507-524. http://doi.org/10.1146/annurev-soc-071811145531

Logan, J. R., Zhang, W., \& Xu, H. (2010). Applying spatial thinking in social science research. GeoJournal, 75(1), 15-27. http://doi.org/10.1007/s10708-010-9343-0

National Reseach Council. (2006). Learning to Think spatially. Washington, D.C.: The National Academic Press. Retrieved from www.nap.edu

NCSS. (2016). A Vision of Powerful Teaching and Learning in the Social Studies, 80(3), $180-182$.

Saekhow, J. (2015). Steps of Cooperative Learning on Social Networking by Integrating Instructional Design based on Constructivist Approach. Procedia - Social and Behavioral Sciences, 197(February), 1740-1744. http://doi.org/10.1016/j.sbspro.2015.07.230

Uttal, D. H. (2000). Maps and spatial thinking: a two-way street. Developmental Science, 3(3), 283-286. http://doi.org/10.1111/1467-7687.00121

Verma, K. (2014). Geospatial Thinking of Undergraduate Students in Public Universities in The United States. Texas State University.

Wiegand, P. (2006). Learning and Teaching with Maps. London and New York: Routledge Taylor \& Francis Group. Retrieved from http://cataleg.udg.edu/record=b1373859 S10*cat 